No 4(61), 2019, p. 111-130

https://doi.org/10.12797/Politeja.16.2019.61.07

\author{
Nicole HORÁKOVÁ (DD \\ University of Ostrava \\ nicole.horakova@osu.cz
}

\title{
NEO-NATIONALISM \\ IN THE CZECH REPUBLIC \\ AND ITS SELF-PRESENTATION \\ ON SOCIAL NET WORKS USING \\ THE EXAMPLE OF FACEBOOK
}

ABSTRACT Neo-nationalistic movements, extreme right-wing organisations, and right-wing parties are booming not only in Europe; they can be found in nearly all western societies, and, in some countries, they form an inherent part of the political system and participate in government, playing an active role in civil society, organising demonstrations and festivals and publicly providing information about their ideas. In doing so they are gaining influence not only on the political scene, but their topics also affect the opinions and debates of the general public. Neo-nationalistic right-wing movements are common in, for example, Germany and France, and especially in the Central European countries of Poland, Hungary, Slovakia and the Czech Republic. They consider themselves to be 'patriots', whose aim is to 'protect' their own national culture and nation as such from foreign life forms and religions. This kind of 'protection' refers mainly to cultural, ethnic and religious issues. In my contribution, I deal with two neo-nationalistic movements in the Czech Republic and analyse how they present themselves on social media (Facebook). The main focus of my research are Internet memes, through which I want to show how the organisations fight against multiculturalism and open society. The present contribution is divided into three parts: first I provide a brief historical overview of the development of right-wing extremism in the Czech lands, the second part deals with the current situation regarding neo-nationalistic movements in the Czech Republic, and the last presents my research on Internet memes 
and attempts at categorising them, aiming not only to show the different types of memes but also to discover the strategies, argumentation and ideas of neonationalistic movements.

Key words: neo-nationalism, multiculturalism, social media, Czech Republic

\section{INTRODUCTION}

Neo-nationalistic movements focus on nation and nation-building. Modern nationalism acts on the assumption that mankind is divided into different nations by nature. Every nation has its own characteristics, which comprise the language, culture, history, and territory. In the concept of modern nationalism, every human being naturally belongs to one well-defined nation, which is at the same time the basis of the national state. ${ }^{1}$ Ernest Gellner is one of the most important researchers and theoreticians of nationalism, and, in his opinion, nationalism is not given by natural circumstances and history, but is the result of social changes caused by the industrial revolution. The unification of bureaucracy, language and the standardization of education have all supported and enhanced the process of nationalisation. ${ }^{2}$

At the beginning of the $20^{\text {th }}$ century, national states tried to avoid migration into their social and cultural systems; they closed their labour markets and their economies to foreign workers and customers. ${ }^{3}$ The modern Czechoslovakian state was established after the First World War in 1918 as a multi-ethnic entity, which was, however, first destroyed by German occupation, and, after the Second World War, by the expulsion of the German population living in the territory of the Czechoslovakian national state. During the communist period the movement of people into and out of Czechoslovakia was strictly limited and controlled; for example, the Czechoslovakian government allowed the arrival of a group of Greek communists in 1950, who were fleeing the civil war, ${ }^{4}$ and the migration of Roma groups from the Slovakian part of the country to industrial areas in Silesia and Bohemia. ${ }^{5}$ A massive wave of emigration occurred in 1968 during the Prague Spring and the subsequent Soviet invasion of Czechoslovakia in $\mathrm{Au}-$ gust of the same year.

\section{J. Charvát, Současný politický extremismus a radikalismus, Praha 2007, p. 32.}

Ibid., pp. 36-38.

3 As an example: J. Oltmer, Migration und Politik in der Weimarer Republik, Götting 2005. Oltmer shows that the German national state at the beginning of the $20^{\text {th }}$ century systematically closed its labour market to Polish and other foreign workers. The possibilities to gain German citizenship were limited.

$4 \quad$ M. Kollerová, “Řecká menšina v Moravskoslezském kraji”, Moderni dějiny, at <http://www.moderni -dejiny.cz/clanek/recka-mensina-v-moravskoslezskem-kraji>, 2 September 2017.

5 N. Pavelč́ková, "Historie romského obyvatelstva v Českých zemích v letech 1945-1989 - Studie”, Moderni dèjiny, at < http://www.moderni-dejiny.cz/clanek/historie-romskeho-obyvatelstva-v-ceskychzemich-v-letech-1945-1989-studie>, 2 September 2017. 
After the Velvet Revolution in 1989, Czechoslovakia and later the Czech Republic changed from an emigration-friendly country into an immigration or transit country for migrants and refugees; from the 1990s the Czech Republic has been one of the target countries for migrants from Vietnam, Russia, Ukraine, Cuba and Bosnia (during the Balkan Civil War), and also for ethnic Czechs from Kazakhstan, Ukraine, and Romania. Nonetheless, compared with the percentage of foreigners in other member states of the European Union (EU average $7.2 \%$ in 2016), the number of foreigners living in the Czech Republic is quite low (4.5\% in 2016). ${ }^{6}$ The Czech government does not offer a special integration policy to foreigners: the only integration goal is their economic and social independence. 7 The question of how to live together with other cultural or ethnic groups was relevant especially in the case of the Roma minority, which was considered inadaptable and had to face racist behaviour coming not only from the Czech majority but also in social, economic, political and structural dimensions. During the 1990s and the beginning of the 2000s, strong ultra-right and nationalistic movements and organisations were highly active, but their position in the party system was relatively weak. ${ }^{8}$

The increase in the migration of refugees from Syria and other predominantly Muslim countries since 2010 and the discussion in the EU about new regulations in the migration policy gave these movements a new impulse. We may observe a growing number of neo-nationalistic organisations and movements, which are active mostly on social networks, but also a shift in their ideas and argumentation. ${ }^{9}$ During the same period, we may note a tendency towards radicalisation in the public and political discourse.

\section{BRIEF OVERVIEW: DEVELOPMENT OF RIGHT-WING EXTREMISM IN THE CZECH LANDS}

In the history of present-day Czech Republic, nationalistic and (extremist) right-wing ideas have a long tradition, with strong roots in the $19^{\text {th }}$ century. The Czech National Revival, which attempted a (re-)birth of the Czech nation, gave rise to a number of myths upon which Czech nationhood has been based to the present day: for example, the belief that the nobility in the Middle Ages already bore a pre-national Czech identity. The extreme right developed in Czechoslovakia among the Czech and the German

$6 \quad$ Europäische Union. Anteil der ausländischer Staatsangehöriger an der Gesamtbevölkerung der Mitgliedsstaaten im Jahr 2016, at < https://de.statista.com/statistik/daten/studie/73995/umfrage/auslaenderanteil-an-der-bevoelkerung-der-laender-der-eu27>, 3 September 2017.

7 An overwiev of the migration policy in the Czech Republic: A. Baršová, P. Barša, Přistéhovalectvi a liberálni stát. Imigračni a integračni politiky v USA, západni Evropě a Česku, Brno 2005, pp. 205-265.

$8 \quad$ M. Mareš, Extremismus v ČR: Pravicový extremismus II - český extremistický nacionalismus. Metodický portál, at <http://clanky.rvp.cz/clanek/c/g/19111/EXTREMISMUS-V-CR-PRAVICOVY-EXTREMISMUS-II---CESKY-EXTREMISTICKY-NACIONALISMUS.html>, 9 September 2017.

9 J. Smolík, "Nové trendy české krajní pravice. New Trends in the Czech Extreme Right", Rexter - časopis pro vyzzum radikalismu, extremismu a terorismu, at <http://www.rexter.cz/wp-content/uploads/ rexter_01_2013_04.pdf>,9 September 2017. 
population separately until 1939. After the establishment of the Protectorate of Bohemia and Moravia in 1939, the Czech lands were fully subordinated to the Great Germanic Reich. Collaborating groups of the Czech extreme right (e.g. the organization Flag/Vlajka) had no ruling position in the occupied protectorate. One of the reasons was that Germans refused to establish combat units of Czech collaborators for a long time. $^{10}$

During the Communist regime, established in 1948, Nazi trends occurred in the Czechoslovakian Socialist Republic sporadically. We occasionally find them among certain rebelling youth groups. As an example, we can mention the newly established skin-head culture, which emerged in the ČSSR in the second half of the 1980s. ${ }^{11}$

The political, economic, and social changes after the Velvet Revolution in 1989 gave right-wing extremist groups the possibility to develop their own profile and establish themselves in the political system. Mareš mentions the 1990s as the golden era of the extreme right in the Czech Republic. ${ }^{12}$ The most successful groups in the 1990s and the first decade of the $21^{\text {st }}$ century were the Republican Party of Czechoslovakia with its chairman Miroslav Sládek (the party was represented in parliament from 1992-1998) and the Workers' Party (Dělnická strana), founded in 2002 and still active. The current situation of the Workers' Party is described in the quarterly report of the Ministry of the Interior of the Czech Republic from 2017 concerning extremist activities: The party more or less left public space and still remains in a process of regression. ${ }^{13}$ Even though both groups were highly active in the 1990s and the first decade of the new century, their position in the party system remained relatively weak.

Until 2010 extreme right-wing parties in the Czech Republic were mostly focused on ethnic minorities like the Czech Roma population or Jews. Further, non-ethnic groups such as homosexuals, homeless people and disabled people were in the centre of their attention. The 'others' were described as 'uncivilized' and 'unassimilated' to the values of the society, and were seen as parasites on the social system and criminals. ${ }^{14} \mathrm{Refu}-$ gees, migrants and Muslims were relatively ignored. Research conducted by the Ministry of the Interior titled "Mapping the public attitude in the Czech Republic towards right-wing extremism, racism, xenophobia, and the disseminators of these thoughts considering the integration of minorities and foreigners" showed that about $8 \%$ of the Czech population could have been affected by the ideas of the extrem right-wing. This mainly concerns people who take an active part in demonstrations and other events

10 M. Mareš, "National and Right-Wing Radicalism in the New Democracies. Czech Republic", Paper for the workshop of the Friedrich Ebert Foundation on "Right-Wing Extremism and its Impact on Young Democracies in the CEE Countries", Praha 2011, pp. 6-8.

11 Ibid., p. 8.

12 M. Mareš, "Czech Extreme Right Parties an Unsuccessful Story", Communist and Post-Communist Studies, vol. 44 (2011), pp. 283-298. Here p. 284.

13 Ministerstvo vnitra České republiky, Extremismus souhrnná situační zpráva 1. čtvrtletí 2017, p. 4.

14 Ministerstvo vnitra České republiky, Zmapování postojů veřejnosti v České republice k pravicově extremistickým, rasistickým a xenofobním myšlenkám a jejich šiřitelům s ohledem na integraci menšin a cizinců, Praha 2010, p. 7. 
organised by right-wing extremist organisations. The survey claimed that about $5 \%$ of the potentially affected people could be counted within this group. ${ }^{15}$

\section{RIGHT-WING EXTREMISM AND NEO-NATIONALISM IN THE CZECH REPUBLIC TODAY}

The right-wing spectrum is widely spread; extreme right and racist Nazi groups also belong in this spectrum as neo-nationalistic, patriotic or ultraconservative movements and organisations. Today's right-wing and neo-nationalistic movements include not only political parties but also a wide range of different types of movements and informal, unregistered sub-groups. ${ }^{16}$ As seen from their different shapes, their image is very heterogeneous. Recent years, however, have seen an ideological and strategic transformation within these groups to evoke a change in their public image. Right-wing national slogans, xenophobia and ideas of the extreme right are becoming more and more socially acceptable. Also, young people are affected by right-wing propaganda, which spreads mainly through new communication channels such as social networks like YouTube, Instagram, Facebook and Twitter. ${ }^{17}$

In November 2016, a list of more than 42 so-called nationalistic and patriotic parties, organizations and movements was published; those that define themselves as patriotic groups fighting against migration and Islamization of the Czech Republic. ${ }^{18}$ Other sources mention more than 75 groups existing in the Czech Republic. ${ }^{19}$ What all these groups have in common is that they emphasise their positive relationship with the Czech nation, Czech history and Czech nation-building. Mystifications and romantic views of the past are typical of their propaganda. The term 'nation' is of special importance in their argumentation, as they attach very emotional connotations to it and present it as something unique, in the form of an organic unit. These culture-oriented nationalistic movements pay more attention to folk culture and traditions than to global, 'upper-class' or modern culture. ${ }^{20}$ This kind of cultural nationalism is closely connected to cultural racism and Ethnopluralism, which stress the belief that members of other races are mainly carriers of other cultures. These cultures, from the viewpoint of their argument, are incompatible with the European culture or civilization. This kind of racism is normally linked to general xenophobia, which is directed against all foreigners. ${ }^{21}$

\footnotetext{
Ibid., p. 13.

J. Smolík, Nové trendy...

17 J.M. Berger, "Nazis vs. ISIS on Twitter: A Comparative Study of White Nationalist and ISIS Online Social Media Networks", Program on Extremism, University of Washington. Washington 2016.

18 V. Beran, “42 «vlasteneckých» a nacionalistických skupin v Česku”, Echo24.cz, 13 November 2016, at < http://echo24.cz/a/in5pD/42vlasteneckychanacionalistickychskupinvcesku>, 10 May 2017.

19 Ibid.

20 J. Charvát, Současný politický extremismus a radikalismus, Praha 2007, p. 40.

21 Ibid., pp. 40-41.
} 
In some countries, we can see an aversion against particular ethnic groups, such as the Roma people in the Czech Republic. They are seen as the ones to be blamed for the bad economic situation, the inefficiency of the social system, and the increase in the crime rate.

Since 2013, a shift in the topics of the nationalistic and patriotic movements has been evident; they had previously mostly inveighed against the ethnic group of Czech Roma. Foreigners in general, Muslims and black people were not in the focus of their attention.

The change in the social and political atmosphere in Czech society is a long-term process caused by different circumstances:

- Long-term disillusionment and lack of faith of voters in the democratic political system of the Czech Republic and its representatives. One visible argument is decreasing voter participation since $1996(-16 \%){ }^{22}$

- Corruption scandals at all institutional levels exacerbated the electorates' opinion that politicians do not act in the general public interest, but want to only enrich themselves. ${ }^{23}$

- Elected political elites are supporting populist discourse in the Czech Republic, such as the former president Václav Klaus, who openly endorses the xenophobic ideas of the German party AfD (Alternative für Deutschland). ${ }^{24}$ Polarizing, frightening and populist argumentation frequently recurs in the public discourse.

- Economic, political and financial uncertainty makes most of the Czech population feel insecure. Access to financial wealth is becoming, due to neo-liberalism and globalization, less and less equal, and most people are searching for simple answers in a complicated world. ${ }^{25}$ The economic crisis of 2006-2008 also had a great impact on the Czech economy, and due to the Euro-crisis of the southern EU-member states, people throughout the European Union were confronted with changes, instability and uncertainty more than ever. Furthermore, the rate of unemployment in the Czech Republic was still high, and politicians started introducing reforms to create a better starting position for the Czech economy. Still, the society could be divided into those who gained from the economic crisis, and those negatively affected by the economic breakdown, the unemployed, who are greatly dependent on the social welfare system and have little or no prospect of a positive future.

22 A. Kinnell, “Co je zdrojem politické deziluze v České republice?”, Britské listy, 1 September 2017, at <https://blisty.cz/art/87916.html>, 5 September 2017.

23 Ibid. The author describes three examples of the most important corruption scandals since 2004 . He argues that one of the reasons for the election success of Andrej Babiš is his image of a rich and successful businessman. Voters were of the opinion that he should be able to resist corruption. However, the latest investigations show that he is also part of the corrupt system.

24 T. Halík, "Strašidlo populismu v globalizovaném světě", Náboženství a společnost, June 2017, at <http://halik.cz/cs/tvorba/clanky-eseje/nabozenstvi-spolecnost/clanek/350>, 6 September 2017. Ibid. 
- With the economic crisis in the southern EU-member states, another issue was brought to the foreground: these states were the first place where migrants from Africa and Middle-East had to apply for asylum. Low standards in housing, administration and social care forced most migrants to move to other European countries in the Schengen area. The so-called 'migration crisis' arose in 2010 but became publicly visible in 2013 and then reached its peak in 2015.

All these factors led to a change in the perception of the world of the Czech nationalistic and patriotic movements: the Roma people were not the main target anymore, as they shifted their attention to migrants from Africa and asylum seekers from Syria and the Muslim community in general. The third group to fall within the focus of the Internet activities of nationalistic and patriotic groups is comprised of Czechs and $\mathrm{Eu}-$ ropeans supporting migrants, refugees, and cultural diversity.

\section{METHODOLOGY AND CONCEPTION OF THE RESEARCH}

In my contribution, I focus on the self-presentation of two organisations of the Czech right-wing and nationalistic spectrum, based on their Facebook profiles: ${ }^{26}$ "pro-vlast. org" (for homeland) and "Islám v České republice nechceme" (IvČRN) (We do not want Islam in the Czech Republic). Both organisations oppose multiculturalism, migration, Islam, and refugees, and want to protect their homeland and the Czech national identity. The main research data are Internet memes, which are a very popular communication tool among Internet users. Internet memes can be defined as digital objects that riff on a given visual, textual or auditory form and are then appropriated, recoded, and slotted back into the internet infrastructures they came from..$^{27}$ By liking and sharing them, Internet users disseminate them in the social network and let other users see their preferences. The 'success' of an Internet meme can be measured by the number of likes and shares it garners. Because memes involve constant interaction among texts, readers, and authors in the form of sharing or liking them, ${ }^{28}$ they can be the key to understanding social and cultural processes. They are usually formed based on certain websites, so-called meme generators. The simplicity of their use makes it easy to create simple internet memes accessible to most network users. Because it is so easy to create Internet memes, and because of the absence of formal gatekeeping people, ${ }^{29}$ we would expect a great variety of meme types. However, in reality, participants tend to mould their memetic contributions, according to a surprisingly small number of formulations ${ }^{30}$

26 I have chosen Facebook for my research because it is the most common social network in the Czech Republic with a great number of users.

27 L. Nooney, L. Portwood-Stacer, “One Does Not Simply: An Introduction to the Special Issue of Internet Memes”, Journal of Visual Culture, vol. 13, no. 3 (2014), pp. 248-252, here p. 249.

28 L. Shifman, "The Cultural Logic of Photo-Based Meme Genres", Journal of Visual Culture, vol.13, no. 3, pp. 340-358, here p. 342 .

29 Ibid., p. 342.

30 Ibid. 
and pictures. These circumstances are interpreted by Shifman as an attempt of the participants to create a sense of community in a fragmented world. ${ }^{31}$ Memes can be compared with folkloristic fairy tales, an ancient, mostly orally practised form of spreading and sharing information among people. The strategies for establishing plausibility and legitimization of the presented contents as true representations of (past) events are the same in folklore and contemporary viral internet memes. ${ }^{32}$

\section{THE METHODOLOGY OF COLLECTING AND ANALYSING VISUAL DATA}

The methodology of collecting and analysing visual data has been gaining importance in social sciences in the last 25 years (pictorial turn), because we increasingly rely on visual means (e.g. symbols, logos and trademarks) in contemporary cultures for defining and communicating our identities and social worlds. ${ }^{33}$ We can even find appropriate approaches in related social sciences like ethnology, or in the humanities, such as in history of art or semiotics. New methodological approaches try to enhance the methodology of Grounded Theory also for interpreting visual data. ${ }^{34}$ Based on the assumption of Glaser and Strauss that all is data,${ }^{35}$ Konecki developed a method of analysing visual data following the principles of Grounded Theory. With his concept of 'multislice imagining' Konecki shows that visual data are multilayered reality and echo the claim that reconstructing multilayered phenomena is the main goal of qualitatively generated social theory. ${ }^{36}$ Konecki proposes several steps for analysing visual data: the researcher has to consider the act of creation of visual data, the participation in demonstrating/communicating visual images, the visual product and its content, and finally the reception of the visual objects and images by others and by their creator. ${ }^{37}$ These steps are not built in succession but refer permanently to each other to obtain a 'multislice' interpretation. In his methodology, Konecki uses further elements of GTM like 'open coding', writing memos, selective coding, comparing visual data, and theoretical sampling. ${ }^{38} \mathrm{Mey}$ and

31 Ibid.

32 J. Kajfosz, "Faktoid i mistifikacja w nowych mediach, czyli o strategiach czarowania umysłu", in P. Grochowski (ed.), Netlor. Wiedza cyfrowych tubylców, Toruń 2013, pp. 65-90, here p. 71.

33 K.T. Konecki, "Visual Grounded Theory: A Methodological Outline and Examples from Empirical Work”, Revija za sociologiju, vol. 41, no. 2 (2011), pp. 131-160, here p. 132.

34 Ibid. G. Mey, M. Dietrich, "Vom Text zum Bild - Überlegungen zu einer visuellen Grounded-Theory-Methodologie”, Forum: Qualitative Sozialforschung / Forum Qualitative Social Research (FQS), vol. 17, no., art. 2, no pages (May 2016), at <http://nbn-resolving.de/urn:nbn:de:0114-fqs160225>, 24 August 2017; Y. Kautt, "Grounded Theory als Methodologie und Methode der Analyse visueller Kommunikation”, FQS, vol. 18, no. 3, art. 8, no pages (September 2017). Ibid.

K.T. Konecki, "Visual Grounded Theory...”, p. 139

Ibid., pp. 141-142.

38

Ibid. pp. 142-151. 
Dietrich point out the difference between visual data and 'other' data, e.g. interviews or text. They recommend focusing more on the compositional and aesthetic characteristics of pictures to decode the picture as a communication medium with formal composition. ${ }^{39}$ It is important to emphasise that the development of a methodology for visual data based on GTM is in its infancy, as Konecki, Mey and Dietrich, and Kautt point out in their contributions. ${ }^{40}$

In my contribution, I will try to analyse my (visual) data through the framework of the above-mentioned methodological thoughts and approaches, because, in my opinion, visual grounded theory represents a good tool for analysing internet memes. The data were produced, shared and commented on by internet users to create and spread social reality. I am interested in the topics neo-nationalistic organisations are dealing with, and how they present them in their memes. For this reason, I analysed approximately 60 memes posted by pro-vlast.org and IvČRN on their Facebook profiles between January and August 2017. One category I found in my research is that of 'multiculturalism, which can be divided into several sub-categories. My analysis presents some aspects of the attitude and 'world view' of the neo-nationalistic movements towards multiculturalism and multicultural society.

There are four sub-categories, and the analysed memes concerning 'multiculturalism' can be divided into:

- Multiculturalism as an example of 'bad practice' in foreign countries

- Multiculturalism as an example of 'bad practice' in the Czech Republic

- Ethnopluralism or the glorification of one's own culture as an example of 'good practice'

- Ruler of the World: Multiculturalism as part of conspiracy theories

\section{Multiculturalism as an example of 'bad practice' in foreign countries}

The neo-nationalistic movements like pro-vlast.org consider some European countries to be multicultural, such as France, Sweden, Germany, or Austria. The situations in these countries shown in the memes illustrate that multiculturalism will lead to chaos, crime, financial disaster and Islamisation of the national culture. The 'destructive power' of multiculturalism is pointed out in different ways, as shown in the following memes:

Presentation of violence: in connection with France, presentation of violence is used in the memes: burning cars or rubbish bins, masked demonstrators on the street covered in smoke, policemen attacked by groups of protesters. Another meme shows scenes in France on New Year's Day: the Eiffel Tower seems to be leaning to the side, cars are burning. These memes create the impression that France and especially Paris are out of control and ruled by violent migrants. The leaning Eiffel Tower is a symbol of

39 G. Mey, M. Dietrich, "Vom Text zum Bild...”.

40 Ibid.; K.T. Konecki, “Visual Grounded Theory...”, p. 133; Y. Kautt, “Grounded Theory...”. 
the falling nation; the burning cars a symbol of the chaos multiculturalism brings into society. The pictures of violence are commented on by pro-vlast.org as: The situation in multicultural Paris is in ferment, violent civil disturbance in most of the suburbs and also near the historical city centre: most violent demonstrations are of course in the no-goareas, that is, where the migrants live. Czech media do not inform us about it, so we give you a brief outline with this collage. ${ }^{41}$ The 'Eiffel Tower meme' shows not only violent pictures but also provides 'hard facts': 945 cars were burned on New Year's Day, and 454 people were arrested. The French government asserted that the night was calm, without any bigger trouble. ${ }^{42}$ Pro-Vlast.org comments on this meme with the words: Slightly past date, but here are two fascinating numbers concerning New Year's Day in France. In spite of the fact that most of the damage can be found near the areas where nonEuropean migrants live, allegedly, we do not need to worry. But form your own opinion. ${ }^{43}$

Figure 1: 'Bad Practice' in Foreign Countries: New Year's in France

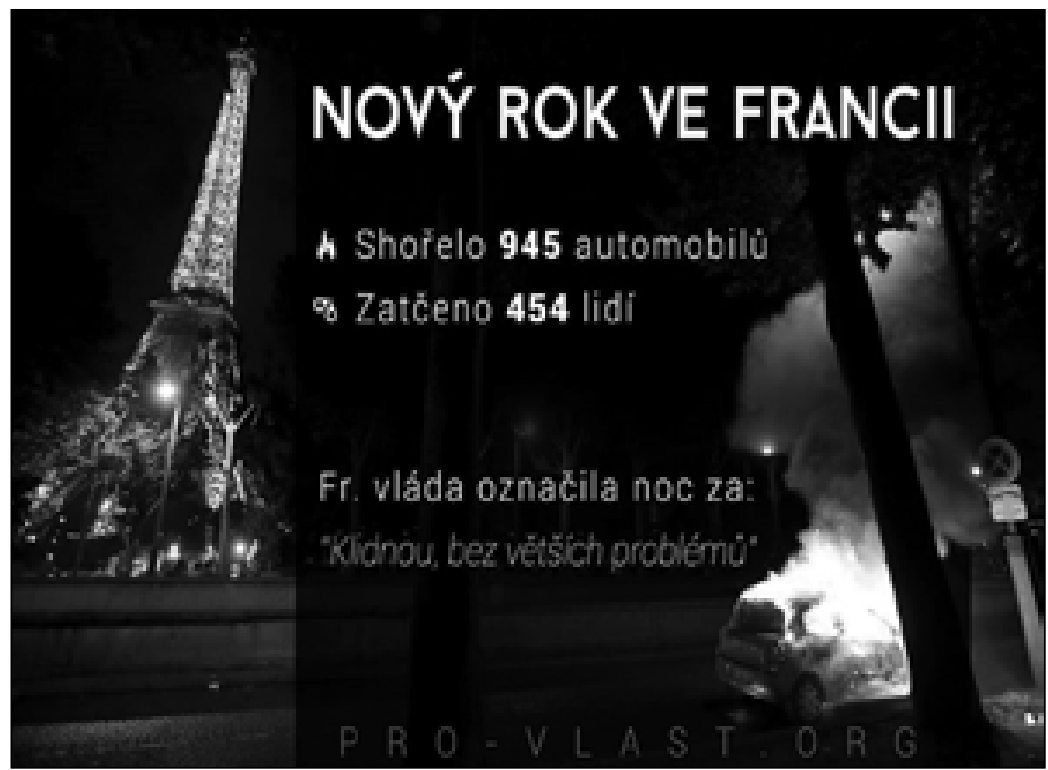

Source: <https://www.facebook.com/ProVlast/photos/a.675364422481987.1073741828.6580604775 45715/1417954038223018/?type=3\&theater $>, 12$ May 2017

The main messages conveyed by these memes are that multiculturalism and migration will bring violence into the otherwise peaceful society because immigrants are aggressive and want to destroy the existing order. The 'mainstream media' (here Czech

41 <https://www.facebook.com/ProVlast/photos/a.675364422481987.1073741828.6580604 77545715/1447473428604412/?type=3\&theater $>, 12$ May 2017.

42 <https://www.facebook.com/ProVlast/photos/a.675364422481987.1073741828.6580604 77545715/1417954038223018/?type=3\&theater>, 12 May 2017.

43 Ibid. 
television) do not show these pictures, because they do not want to alarm the Czech people and want to prepare them for the multicultural society that is going to be established in the Czech Republic. Pro-vlast.org, however, informs the Czech nation about the events taking place around the globe; they tell the "truth" about multiculturalism and try to avert such a situation in the Czech Republic.

Figure 2: 'Bad Practice' in Foreign Countries: The Example of Sweden

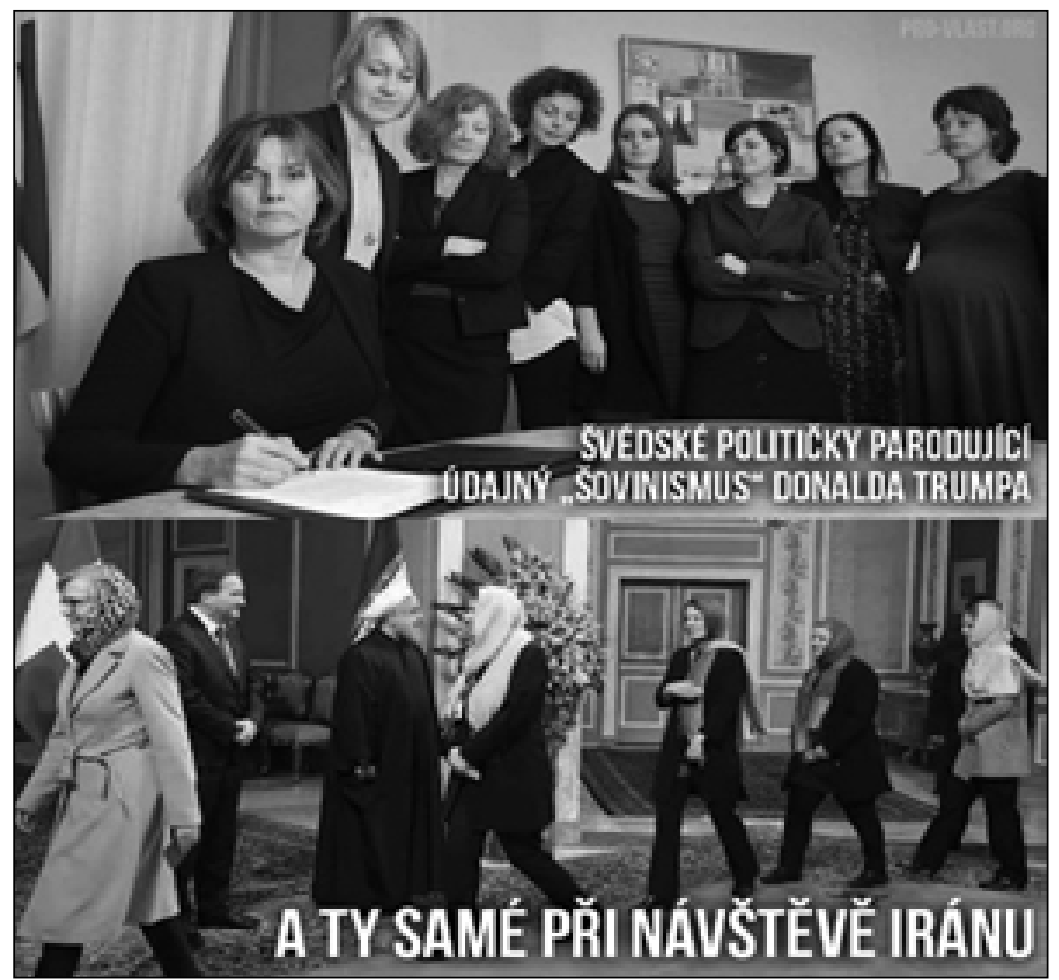

Source: <https://www.facebook.com/ProVlast/photos/a.675364422481987.1073741828.6580604775 45715/1445933168758438/?type=3\&theater $>, 12$ May 2017

Another example is Sweden: for neo-nationalistic movements, it is not only the multicultural state par excellence in Europe, but it is also at risk of being ruled by women. Feminism, equal pay for men and women, and working women are achievements the right-wing organisations are firmly refusing. From their point of view, the woman's role is to take care of the family, motherhood and household. In the analysed meme $e^{44}$ we can see the Swedish Vice Premier Isabella Lövin signing a document, surrounded by her female colleagues. This picture mocks the political practice of the US President Donald Trump, who arranged a similar tableau in the same way but surrounded by his

44 <https://www.facebook.com/ProVlast/photos/a.675364422481987.1073741828.6580604 77545715/1445933168758438/?type=3\&theater>, 12 May 2017. 
male staff. The second part of the meme shows Swedish politicians during a state visit in Iran. The women in the delegation are wearing scarves, as required by Iranian law. This public appearance of the politicians was discussed in the media worldwide, and in some articles, their behaviour was severely criticised ${ }^{45}$ because members of the Swedish government call themselves the first feminist government in the world. The articles in the world press were balanced, pointing out the pros and cons of this public appearance of the female members of the Swedish delegation in Iran. The meme published by pro-Vlast.org brings together only two facts: on the one hand, the Swedish politicians are criticising president Trump's policy as chauvinistic, and on the other hand, they respect the traditions of an Islamic country which represses women's rights. The conclusion from the neo-nationalistic point of view is very simple - these women are playing a double game: they pretend to be feminists in the Western world, and at the same time support Islamic traditions repressing women's rights in Iran. pro-vlast.org wrote the following about the meme: This time with no comment ${ }^{46}$ however, the users are commenting on this meme very tartly and consider the Swedish politicians to be traitors of their nation and of European values. ${ }^{47}$

The last examples are memes showing 'hard facts' about migration to Germany ${ }^{48}$ and Austria. ${ }^{49}$ These info-graphics evaluate the numbers of 'immigrants' and the costs for the German and Austrian states. The 'objectivity' of the memes is supported by Internet sources given at the bottom of the memes: Pro-vlast.org used information from Austrian "Die Kronen-Zeitung", a popular tabloid newspaper, and from the Federal Statistical Office of Germany. In both memes, the presented data are correct, but they are put in an imprecise context: the data published by "Die Kronen Zeitung" and the Federal Statistical Office concern refugees and asylum-seekers in Austria and Germany. Because of the 'refugee crisis' in 2015, the numbers of asylum-seekers increased and the governments had to invest more money in social welfare. The info-graphics of provlast.org talk only about 'migrants', 'immigrants' or 'foreigners', while the sources stress that the numbers increased because of the 'refugee crisis' and try to explain the specific position of asylum-seekers in the social welfare system of Austria and Germany. The imprecise use of the terms in the info-graphics implies that both states spend a lot of money on foreigners who are searching for a better economic life in Europe. The use of pejorative terms concerning the asylum-seekers should suggest that they receive financial support illegally. In connection with both memes, pro-vlast.org claims that the data

45 E.g. Hillel Neuer, director of the NGO "UN Watch", deemed this activity of the Swedish delegation as a "Walk of shame" see at <https://www.welt.de/politik/ausland/article162047481/Scharfe-Kritik-an-Schwedens-feministischer-Regierung.html>, 20 September 2017. 77545715/1445933168758438/?type=3\&theater>, 12 May 2017.

47 Ibid.

48 <https://www.facebook.com/ProVlast/photos/a.675364422481987.1073741828.6580604 77545715/1286105871407836/?type=3\&theater >, 12 May 2017. 
about migration and social welfare were finally published, and further: Let's have a look at our new info-graphic, let's learn a lesson and make sure that we really do not want mass immigration into our country..$^{50}$

\section{Multiculturalism as an example of 'bad practice' in the Czech Republic}

About 1,500 people applied for asylum in the Czech Republic in 2015, but only 71 applicants were officially acknowledged as asylum-seekers. The percentage of all foreigners legally living in the Czech Republic remains under 5\%. ${ }^{51}$ Czech society is homogenous: coexisting with foreigners and encountering them in everyday life is still rare. Ghettos, where only migrants live, 'no-go-areas', are just as uncommon as violent demonstrations of migrants against social injustice or discrimination. In the memes of this category, however, we find politicians or intellectuals who want to establish a more colourful and multicultural society in the Czech Republic.

Figure 3: 'Bad practise' in the Czech Republic: For a Colourful and Multicultural Society

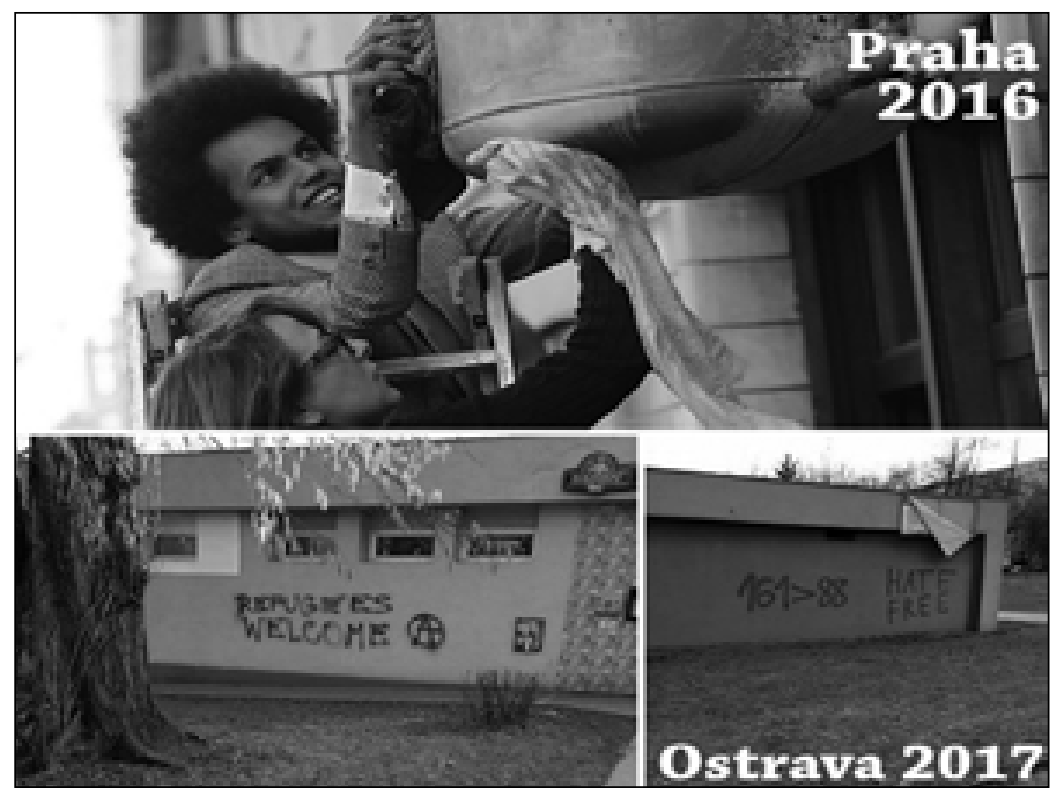

Source: <https://www.facebook.com/ProVlast/photos/a.675364422481987.1073741828.6580604775 45715/1461988360486252/?type=3\&theater $>, 12$ May 2017.

50 <https://www.facebook.com/ProVlast/photos/a.675364422481987.1073741828.6580604 77545715/1286105871407836/?type=3\&theater>, 12 May 2017.

51 See also N. Horáková, "Bilder von Flüchtlingen in sozialen Netzwerken - eine soziologische Analyse von Internet Memes in tschechischen sozialen Netzwerken”, in M. Mazurkiewicz, A. Franke, T. Siwek, M. Moj (eds.), Colloqium Opole 2016, Polska, Niemcy, Czechy wobec wyzwania migracji i integracji, Opole 2017, pp. 145-171. 
One meme shows the Czech politician Dominik Feri, a member of the liberal party TOP 09. ${ }^{52}$ What makes this politician unique in the context of the Czech Republic is that he is very young and has dark skin. In the meme, he is cleaning the front of an autonomous centre in Prague, which has been attacked by neo-Nazis. The autonomous centre is engaged in a 'Hate free' movement, which stands up for a multicultural society and welcomes refugees. The spray paint attack by neo-Nazis against the autonomous centre was criticised not only in the media but also by politicians and other groups of civil society. The meme with Dominik Feri also shows another picture: a pub in Ostrava spray-painted with 'Hate free' slogans, such as 'Refugees welcome' or ' $161>88$ ',53 but the politician does not care, and cleans the other building of anti-fascistic slogans. In the comment, pro-vlast.org points out that the same things (spray paint attacks on buildings) tend to be viewed: right-wing slogans are worse and young politicians try to remove them (with a media campaign), left-wing slogans are accepted and nobody cares. Pro-vlast.org complains about such kind of injustice and wants to show that politicians support 'multiculturalism'.

Another meme is about a student of sociology from Charles University in Prague, who is involved in different activities of civil society, such as demonstrations against right-wing movements and helping refugees. ${ }^{54}$ Her engagements and her research on gender are trivialized in the followers' comments as follows: She should work hard instead of study silly things like gender and get paid from the taxes of us normal workers. ${ }^{55}$ The organisation 'Bloc against Islam', that posted this meme, commented: Do you know what Charles University students do the whole day? They fight for Islam and for shared toilets for men and women..$^{5}$ This is followed by a remark about the budget of Charles University and how much money a junior professor earns each month - money which comes from the taxes paid by workers. I include these two memes as examples from the category of Czech 'bad practice' which communicate the same message: politicians and intellectuals want to establish a multicultural society, but they do not understand the common people, the workers who pay taxes, the Czech people who love their homeland. Politicians and intellectuals use their influence and power to persuade the Czech society that multiculturalism is the right way to go, the way we should choose. In fact, however, they engage in useless nonsense and do not care about the real-life problems of the Czech people.

\footnotetext{
52 <https://www.facebook.com/ProVlast/photos/a.675364422481987.1073741828.6580604 77545715/1461988360486252/?type=3\&theater $>, 12$ May 2017.

53 ' $161>88$ ' means 'antifascism campaign > Heil Hitler.'

54 <https://www.facebook.com/blokprotiislamizaci/photos/a.568841073292612.1073741827. $441997272643660 / 711502655693119 /$ ?type=3\&theater $>, 12$ May 2017.

55 Ibid.

56 Ibid.
} 


\section{Ethnopluralism or the glorification of one's own culture as an example of 'good practice'}

The main terms in the thinking of neo-nationalistic and patriotic movements are 'own nation' and 'national culture'. It is very important to strengthen solidarity and the nation's identity. That also means excluding those who are not members of the national community by birth. Place of birth, however, is not the only condition of being part of the national culture; another criterion is one's descent. By this, neo-nationalistic movements create mechanisms of inclusion and exclusion: who belongs in our nation and who does not? Neo-nationalistic movements avoid using the term 'race' and replace it with the more sophisticated word 'culture'. In their opinion, different cultural groups and ethnic communities worldwide have the right to exist and to practise their culture and traditions, but every culture should remain within its own territory and should not mingle with other ethnic groups. Neo-nationalistic movements understand culture as a closed box in a special space (here the territory of the national state): everybody who grew up in this 'box' is deeply rooted in their culture and inherits the traditions and the cultural values from their ancestors. This way, national cultures have been evolving for hundreds, thousands of years. In the neo-nationalistic opinion, culture does not change, does not take other shapes and is not influenced or affected by the surrounding world. ${ }^{57}$ The Facebook profile of pro-vlast.org shows many memes dealing with 'Czech cultural heritage' and events from Czech history.

A good example is a meme with the slogan: Strong values make a strong culture. ${ }^{58} \mathrm{In}$ the background, we can see the stained-glass window of St. Vitus' Cathedral in Prague, designed by the Czech Art Nouveau painter Alfons Mucha. The stained-glass window belongs in the cycle of nationalistic iconography Mucha created in 1920. Mucha surrounds St. Wenceslas, the patron of the Czech nation, with scenes from the lives of Slavic saints. The middle of the window from top to bottom compiles 1,000 years of national history: Wenceslas is famous as the uniter of the Bohemian lands, who fought against oppression by neighbouring rulers. When the stained-glass window was installed in 1931, the political context was not far away: Wenceslas obviously personifies the fledgling Czechoslovakian state created in 1918 after centuries of 'parental rule' by the Habsburg Empire that disintegrated after World War I. ${ }^{59}$

Another group of memes belonging in this category shows activities undertaken by members of neo-nationalistic movements themselves. They fight for their own culture and stand up against the (multicultural) state system by hanging up banners, spraying graffiti and organising flash mobs via social media. All these activities are normally

57 I. Leicht, "Was kann denn dieser Mohr dafür, dass er so weiss nicht ist wie ihr? Es lebe die Rassenvielfalt! Wie sich die Neue Rechte der multikulturellen Identitätspolitik bedient”, Jungle Word, vol. 49 (2009), at <http://jungleworld.com/artikel/2009/49/39952>, 19 May 2017.

58 <https://www.facebook.com/ProVlast/photos/a.675364422481987.1073741828.6580604 77545715/1429436303741458/?type=3\&theater>, 12 May 2017.

59 <http://rijksmuseumamsterdam.blogspot.cz/2012/03/alphonse-mucha-stained-glass-window. html>, 17 September 2017. 
used by groups belonging to the left-wing spectrum. Neo-nationalistic movements try to create a revolutionary image and establish themselves as grass-roots and bottom-up movements, who stand against the political and intellectual establishment. "Multiculturalism equals genocide" ${ }^{60}$ reads a banner shown in one of the memes: Neo-nationalistic groups believe that migration and living together with other ethnic groups will oppress the 'Czech culture and nation'. In this context we also find the term 'Umvolkung', meaning that the original nation will be replaced by migrants and vanish. In the opinion of neo-nationalistic groups, migration movements are systematic and aim to destroy the nations of Europe.

Figure 4: 'Good practise': Glorification of own Culture and Nation

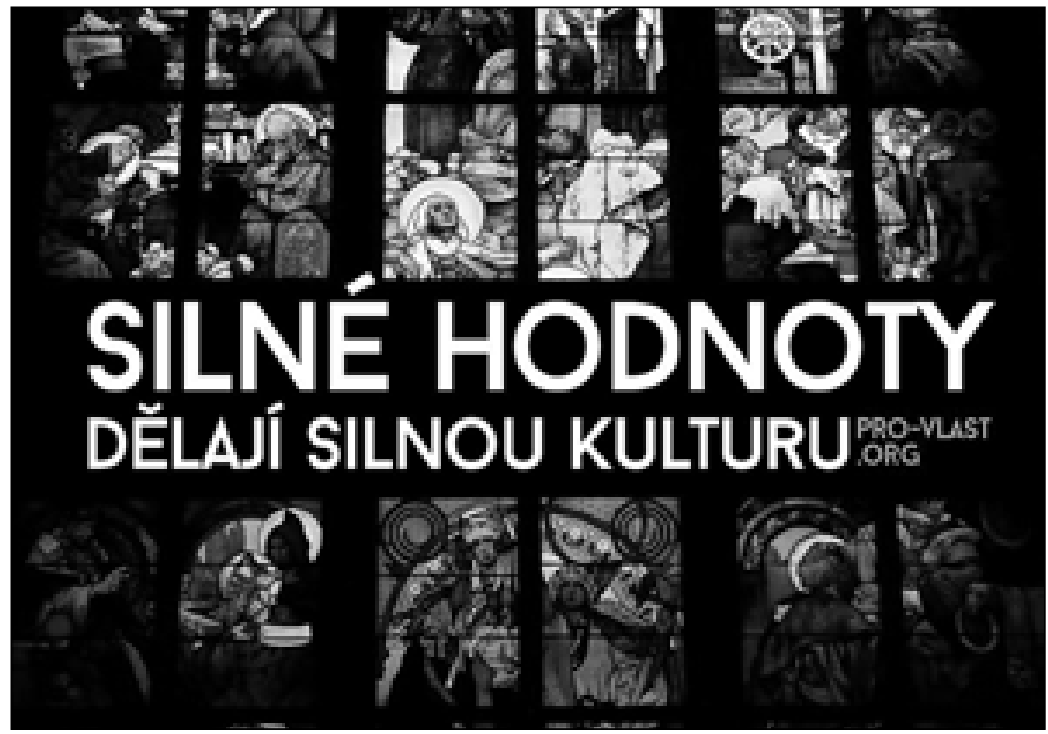

Source: <https://www.facebook.com/ProVlast/photos/a.675364422481987.1073741828.6580604775 45715/1429436303741458/?type=3\&theater >, 12 May 2017

\section{Ruler of the World: Multiculturalism as part of conspiracy theories}

According to the mindset of neo-nationalistic groups, western societies are 'infected' by multiculturalism. Media, advertising and promotion show us the following: diversity and multiculturalism are positive; pure or mono-cultures are something unusual and undesirable. The aim of neo-nationalistic movements is to uncover this praxis and to make the society aware of the methods media and politicians use.

The German supermarket chain LIDL became a focus of neo-nationalistic groups: in 2016, LIDL advertised streetwear worn by black models. The supermarket received

60 <https://www.facebook.com/ProVlast/photos/a.675364422481987.1073741828.6580604

$77545715 / 1184509098234181 /$ ?type=3\&theater $>, 12$ May 2017. 
a backlash on social media. In response to the messages, the management published a statement that LIDL supports diversity and open society, and with this LIDL became an enemy of neo-nationalistic groups. Routinely, neo-nationalists 'discover' promulticultural advertisements in LIDL's leaflets. In a meme dated 3 September 2017, pro-vlast.org called on their followers to boycott LIDL $^{61}$ because the supermarket had retouched a cross on the roof of a church in one of their leaflets. Pro-vlast.org interprets this as an attack on the Czech and Christian culture. ${ }^{62}$

Figure 5: Ruler of the World: Multiculturalism as Part of Conspiracy Theories

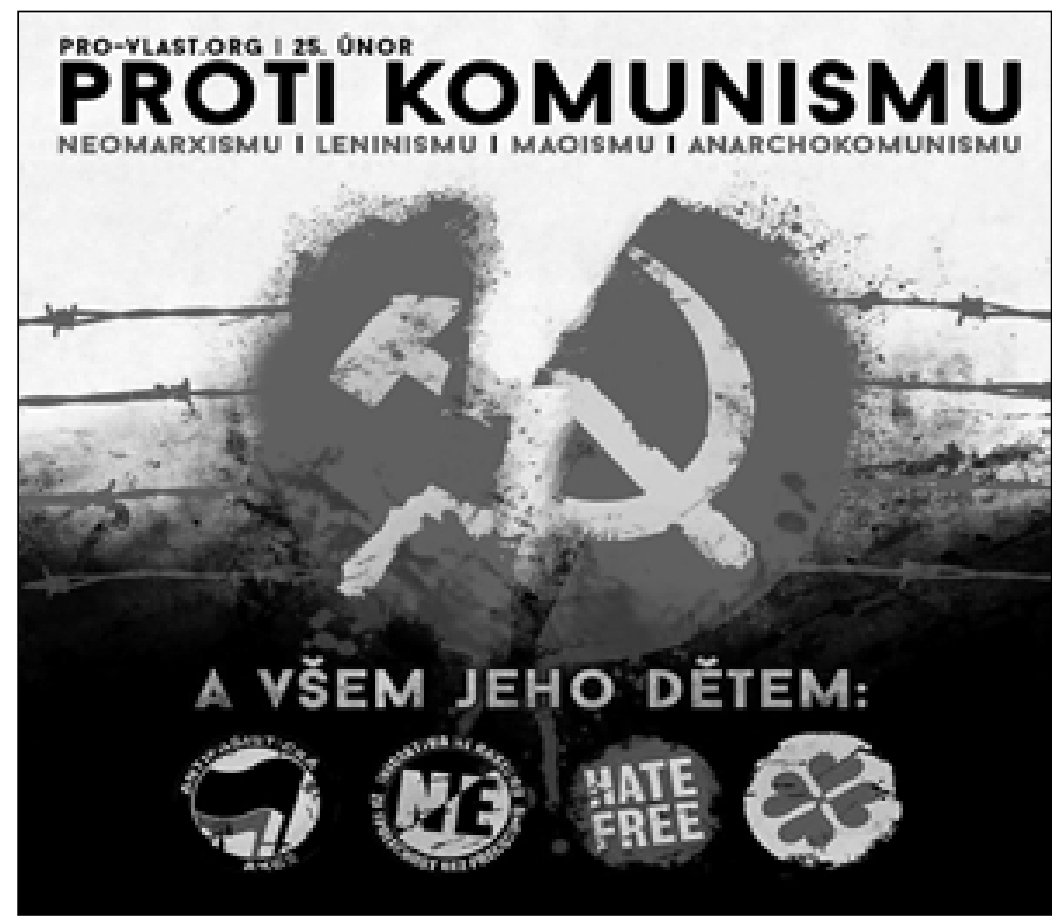

Source: <https://www.facebook.com/ProVlast/photos/a.675364422481987.1073741828.6580604775 45715/1145436085474816/?type=3\&theater $>, 12$ May 2017

From the neo-nationalistic point of view, multicultural theories are linked to other ideas and theories, e.g. Neo-Marxism, Antifascism, Communism, and also to groups like the Green Party, 'Hate free' or any kind of intellectual 'elites. ${ }^{63}$ They cannot understand the needs of the Czech people and support multiculturalism, migration and Islamisation. In doing so, they revile - in the opinion of the neo-nationalists - their own

\footnotetext{
61 <https://www.facebook.com/ProVlast/photos/a.675364422481987.1073741828.6580604 $77545715 / 1655751381109948 /$ ?type=3\&theater $>, 15$ September 2017.

62 Ibid

63 <https://www.facebook.com/ProVlast/photos/a.675364422481987.1073741828.6580604 77545715/1145436085474816/?type=3\&theater>, 15 September 2017.
} 
nation and culture. This kind of thinking works with the same mechanisms of inclusion and exclusion mentioned above: in this argumentation not only are other cultures or ethnic groups excluded, but also different-minded people such as intellectuals and people with other kinds of lifestyles or different sexual orientations.

\section{CONCLUSION}

Neo-nationalistic and patriotic movements can be found in nearly all Western societies, where they are more often than not successful in the political and civil areas. In their argumentation, we can point out a shift from the blunt racism of the previous century to a much more sophisticated line of argumentation under the slogan of 'ethnocentrism. According to these thoughts, culture is the new race. It is important for neo-nationalistic groups to emphasise and underpin their own (Czech) values, history and traditions. Doing so, they want to establish a physical and mental boundary between their own nation and foreigners. They perceive as foreigners not only people who do not have Czech citizenship, but also people who support a point of view different from theirs. They try to depict themselves as victims of the 'establishment', those who tell the truth and defend the nation against negative cultural influences. This attitude is becoming more and more socially accepted. The neonationalistic and patriotic movements in the Czech Republic are not as strong as in other European countries; nonetheless, they use the same arguments, the same kind of ideological background, and they are going to enter the public discourse in a big way.

\section{BIBLIOGRAPHY}

Baršová A., Barša P., Přristěhovalectvi a liberálni stát. Imigračni a integračni politiky v USA, západni Evropè a Česku, Brno 2005.

Beran V., “42 «vlasteneckých» a nacionalistických skupin v Česku”, Echo24.cz, 13 November 2016, at < http://echo24.cz/a/in5pD/42vlasteneckychanacionalistickychskupinvcesku>, 10 May 2017.

Berger J.M., Nazis vs. ISIS on Twitter: A Comparative Study of White Nationalist and ISIS Online Social Media Networks. Program on Extremism, University of Washington, Washington 2016. Europäische Union: Anteil der ausländischer Staatsangehöriger an der Gesamtbevölkerung der Mitgliedsstaaten im Jahr 2016 at <https:/de.statista.com/statistik/daten/studie/73995/ umfrage/auslaenderanteil-an-der-bevoelkerung-der-laender-der-eu27>, 3 September 2017.

Halík T., "Strašidlo populismu v globalizovaném světě", Náboženství a společnost, June 2017 at $<$ http://halik.cz/cs/tvorba/clanky-eseje/nabozenstvi-spolecnost/clanek/350/>, 6 September 2017.

Horáková N., "Bilder von Flüchtlingen in sozialen Netzwerken - eine soziologische Analyse von Internet Memes in tschechischen sozialen Netzwerken”, in M. Mazurkiewicz, A. Franke, T. Siwek, M. Moj (eds.), Colloqium Opole 2016, Polska, Niemcy, Czechy wobec wyzwania migracji i integracji, Opole 2017, pp. 145-171. 
Charvát J., Současný politický extremismus a radikalismus, Praha 2007.

Kajfosz J., "Faktoid i mistifikacja w nowych mediach, czyli o strategiach czarowania umysłu”, in P. Grochowski (ed.), Netlor. Wiedza cyfrowych tubylców, Toruń 2013, pp. 65-90.

Kautt Y., "Grounded Theory als Methodologie und Methode der Analyse visueller Kommunikation”, Forum: Qualitative Sozialforschung / Forum Qualitative Social Research (FQS), vol. 18, no. 3, art. 8, no pages (September 2017), http://dx.doi.org/10.17169/fqs-18.3.2859.

Kinnell A., “Co je zdrojem politické deziluze v České republice?”, Britské listy, 1 September 2017, at <https://blisty.cz/art/87916.html>, 5 September 2017.

Kollerová M., “Řecká menšina $v$ Moravskoslezském kraji”, Moderni dějiny, at <http://www. moderni-dejiny.cz/clanek/recka-mensina-v-moravskoslezskem-kraji/>, 2 September 2017.

Konecki K.T., "Visual Grounded Theory: A Methodological Outline and Examples from Empirical Work”, Revija za sociologiju, vol. 41, no. 2 (2011), pp. 131-160, https://doi. org/10.5613/rzs.41.2.1.

Leicht I., "Was kann denn dieser Mohr dafür, dass er so weiss nicht ist wie ihr? Es lebe die Rassenvielfalt! Wie sich die Neue Rechte der multikulturellen Identitätspolitik bedient", Jungle Word, vol. 49 (2009), at <http://jungleworld.com/artikel/2009/49/39952>, 19 May 2017.

Mareš M., "Czech Extreme Right Parties an Unsuccessful Story”, Communist and Post-Communist Studies, vol. 44 (2011), pp. 283-298, https://doi.org/10.1016/j.postcomstud.2011.10.007.

Mareš M., "Extremismus v ČR: Pravicový extremismus II - český extremistický nacionalismus”, Metodický portál, at <http://clanky.rvp.cz/clanek/c/g/19111/EXTREMISMUS-V-CRPRAVICOVY-EXTREMISMUS-II---CESKY-EXTREMISTICKY-NACIONALISMUS.html/>, 9 September 2017.

Mareš M., "National and Right-Wing Radicalism in the New Democracies: Czech Republic", Paper for the Workshop of the Friedrich Ebert Foundation on Right-Wing Extremism and its Impact on Young Democracies in the CEE Countries, Praha 2011.

Mey G., Dietrich M., "Vom Text zum Bild - Überlegungen zu einer visuellen GroundedTheory-Methodologie”, Forum: Qualitative Sozialforschung / Forum Qualitative social research (FQS), vol. 17, no. 2, art. 2, no pages (May 2016), at <http://nbn-resolving.de/ urn:nbn:de:0114-fqs160225>, 24 August 2017.

Ministerstvo vnítra České republiky, Extremismus souhrnná situační zpráva 1. čtvrtletí 2017.

Ministerstvo vnítra České republiky, Zmapování postojů veřejnosti v České republice $\mathrm{k}$ pravicově extremistickým, rasistickým a xenofobním myšlenkám a jejich šiřitelům $s$ ohledem na integraci menšin a cizinců, Praha 2010.

Nooney L., Portwood-Stacer L., "One Does Not Simply: An Introduction to the Special Issue of Internet Memes”, Journal of Visual Culture, vol. 13, no. 3 (2014), pp. 248-252, https:// doi.org/10.1177/1470412914551351.

Oltmer J., Migration und Politik in der Weimarer Republik, Götting 2005.

Pavelčíková N., "Historie romského obyvatelstva v Českých zemích v letech 1945-1989 - Studie", Moderni dějiny, at < http://www.moderni-dejiny.cz/clanek/historie-romskeho-obyvatelstva-v-ceskych-zemich-v-letech-1945-1989-studie/>, 2 September 2017.

Shifman L., "The Cultural Logic of Photo-Based Meme Genres", Journal of Visual Culture, vol. 13, no. 3, (2014), pp. 340-358, https://doi.org/10.1177/1470412914546577. 
Smolík J., "Nové trendy české krajní pravice. New Trends Czech Extreme Right”, Rexter - časopis pro vyzkum radikalismu, extremismu a terorismu, at <http://www.rexter.cz/wp-content/uploads/rexter_01_2013_04.pdf>, 9 September 2017.

\section{Internet sources of memes}

<https://www.facebook.com/ProVlast/photos/a.675364422481987.1073741828.65806047 $7545715 / 1447473428604412 /$ ?type=3\&theater $>, 12$ May 2017.

<https://www.facebook.com/ProVlast/photos/a.675364422481987.1073741828.65806047 7545715/1417954038223018/?type=3\&theater $>, 12$ May 2017.

<https://www.facebook.com/ProVlast/photos/a.675364422481987.1073741828.65806047 $7545715 / 1445933168758438 /$ ?type=3\&theater $>, 12$ May 2017.

<https://www.welt.de/politik/ausland/article162047481/Scharfe-Kritik-an-Schwedens-feministischer-Regierung.html>, 20 September 2017.

<https://www.facebook.com/ProVlast/photos/a.675364422481987.1073741828.65806047 $7545715 / 1445933168758438 /$ ?type=3\&theater $>, 12$ May 2017.

<https://www.facebook.com/ProVlast/photos/a.675364422481987.1073741828.65806047 $7545715 / 1286105871407836 /$ ?type=3\&theater $>, 12$ May 2017.

<https://www.facebook.com/ProVlast/photos/a.675364422481987.1073741828.65806047 $7545715 / 1451516764866745 /$ ?type=3\&theater $>, 12$ May 2017.

<https://www.facebook.com/ProVlast/photos/a.675364422481987.1073741828.65806047 $7545715 / 1286105871407836 /$ ?type=3\&theater $>, 12$ May 2017.

<https://www.facebook.com/ProVlast/photos/a.675364422481987.1073741828.65806047

$7545715 / 1461988360486252 /$ ?type=3\&theater $>, 12$ May 2017.

<https://www.facebook.com/blokprotiislamizaci/photos/a.568841073292612.1073741827. 441997272643660/711502655693119/?type=3\&theater>, 12 May 2017.

<https://www.facebook.com/ProVlast/photos/a.675364422481987.1073741828.65806047 $7545715 / 1429436303741458 /$ ?type=3\&theater $>, 12$ May 2017.

<http://rijksmuseumamsterdam.blogspot.cz/2012/03/alphonse-mucha-stained-glass-window.html>, 17 September 2017.

<https://www.facebook.com/ProVlast/photos/a.675364422481987.1073741828.65806047

7545715/1184509098234181/?type=3\&theater $>, 12$ May 2017.

<https://www.facebook.com/ProVlast/photos/a.675364422481987.1073741828.65806047

7545715/1655751381109948/?type=3\&theater >, 15 September 2017.

<https://www.facebook.com/ProVlast/photos/a.675364422481987.1073741828.65806047

7545715/1145436085474816/?type=3\&theater >, 15 September 2017.

Nicole HORÁKOVÁ - Dr. phil., M.A. assistant professor at the Department of Sociology at the University of Ostrava, Czech Republic. Master's degree from the Freie Universität, Berlin, postgradual studies at IMIS (Institute for Migration and Intercultural Studies), University of Osnabrück, Germany. Research topics: migration issues, sustainability, changing work environments. 